\title{
Tomato yield and soil chemical attributes depending on previous cover crops
}

\author{
Alexandre G Galvão'; Juliano Tadeu V de Resende²; Rafael Gustavo F Morales'; Sebastião BC Lustosa²; \\ Diego M Dias²; Josué C Marodin ${ }^{1}$ \\ 'UFLA-Dep ${ }^{\text {to }}$ Agronomia, C. Postal 3037, 37200-000 Lavras-MG; galvao.alexandre@hotmail.com; moralescefet@yahoo.com.br; \\ josuemarodin@hotmail.com; ${ }^{2}$ UNICENTRO-CEDETEG, Dep ${ }^{\text {to }}$ Agronomia, C. Postal 3010, 85040-080 Guarapuava-PR; jresende@ \\ unicentro.br; slustosa@unicentro.br; diegomunhozdias@hotmail.com
}

\begin{abstract}
The influence of different cover crops was evaluated over the agronomic performance of tomato hybrids for industrial processing, as well as its effect over soil chemical attributes. The experimental design was completely randomized, in a split plot scheme, with four replications. Main treatments (plots) were composed of winter cover crops (oat, hairy vetch, clover and radish) and of a fallow area (spontaneous vegetation). Subplots were composed of four processing tomato hybrids (AP529, AP533, Kátia and Sicílio). We evaluated the total production (TP), marketable production (CP), average mass of marketable fruits (AMCF) and number of marketable fruits (NCF). Chemical analysis of soil was done in two stages: one week preceding implantation of cover crops and in the phase of tomato implantation. Highest TPs were obtained in treatments in which cover crops were composed by hairy vetch and radish. However, although hairy vetch has caused an increase in TP, no difference between covers was obtained in relation to CP. Sicílio hybrid presented the greatest AMCF, however, its TP was lower than expected. This fact is related to lower NCF, which was half of the observed in AP529 and AP533 hybrids. Radish cover increased phosphorus, calcium and potassium in soil and this could be one of the factors responsible for the increase of TP provided by radish. On the other hand, oat has caused inverse effect, reducing availability of $\mathrm{Ca}$ and $\mathrm{K}$. All covers have increased organic matter in soil, the major increment being presented by oat. Based on these results we conclude that hairy vetch and radish are the most indicated plants for cover preceding tomato cultivation.
\end{abstract}

Keywords: Solanum lycopersicum, winter cover, processing tomato.

\section{RESUMO}

Produtividade do tomateiro e atributos químicos do solo em função do uso de plantas de cobertura antecedendo o cultivo

Foram avaliadas diferentes coberturas de solo sobre o desempenho agronômico de híbridos de tomate para processamento industrial, bem como seus efeitos sobre atributos químicos do solo. $\mathrm{O}$ delineamento experimental foi em blocos casualizados, com quatro repetições, no esquema de parcelas subdivididas. Os tratamentos principais (parcelas) foram constituídos pelas plantas de cobertura de inverno (aveia preta, ervilhaca peluda, nabo forrageiro e trevo vesiculoso) e área em pousio (vegetação espontânea). As subparcelas foram constituídas por quatro híbridos de tomateiro rasteiro (AP529, AP533, Kátia e Sicílio). Foram efetuadas as seguintes avaliações: produtividade total (TP), produção comercial (CP), massa média de frutos comerciais (AMCF) e número de frutos comerciais (NCF). A análise química do solo foi realizada em duas épocas: antecedendo em uma semana a implantação das coberturas de solo e na fase de implantação do tomateiro. As maiores TPs foram obtidas nos tratamentos cuja cobertura do solo foi composta por ervilhaca e nabo. Contudo, apesar da ervilhaca ter proporcionado aumento na PT, não houve diferença entre as coberturas quanto a CP. O híbrido Sicílio apresentou maior AMCF, entretanto, sua TP foi abaixo do esperado. Esse fato está relacionado ao menor NCF, que foi a metade do observado nos híbridos AP529 e AP533. A cobertura nabo incrementou os teores de fósforo, cálcio e potássio no solo, podendo ser esse um dos fatores responsáveis pelo aumento de TP proporcionado pelo nabo. Em contrapartida, a aveia proporcionou um efeito inverso, diminuindo a disponibilidade de $\mathrm{Ca}$ e $\mathrm{K}$. Todas as coberturas aumentaram a matéria orgânica do solo, sendo o maior incremento apresentado pela aveia. Com base nesses resultados pode-se concluir que a ervilhaca e o nabo são as plantas mais indicadas como cobertura de solo antecedendo o cultivo do tomateiro.

Palavras-chave: Solanum lycopersicum, coberturas de inverno, tomate para processamento.

\section{(Recebido para publicação em 26 de junho de 2012; aceito em 31 de outubro de 2012)} (Received on June 26, 2012; accepted on October 31, 2012)

$\mathrm{T}$ here are new processing tomato production centers in the southern region of Brazil. The tomato is cropped at the end of spring, so that the management of the winter cover crop that precedes tomato cropping is important to maximize the productive potential of the cover crop. Increased organic matter (Borkert et al., 2003) and erosion control (Baets et al., 2011) are the main benefits obtained by including cover crop plants in the cropping system. However, the cover crop plants can also improve the soil structure, nematode, pathogen and pest control, water retention capacity and positively influence the yield of the subsequent crop (Sainju et al., 2006).

Nutrient cycling via soil cover crop plants plays an important role in agricultural systems. Legumes can increase the nitrogen $(\mathrm{N})$ content in the soil, mainly because they have a low carbon/nitrogen $(\mathrm{C} / \mathrm{N})$ ratio. Thus 
they decompose quickly, decreasing the time of soil protection against erosion (Aita et al., 2001). In contrast, grasses are characterized by high $\mathrm{C} / \mathrm{N}$ ratios in their straw, that results in lower decomposition rates, greater protection of the soil against erosive processes and lower N release rate (Aita \& Giacomini, 2003).

Oats (Avena strigosa) is the soil cover crop most cultivated in South Brazil. It has several benefits, such as easy seed acquisition and planting, robustness and quick cover formation (Aita et al., 2001). However, $\mathrm{N}$ release from its residues is slow because of the high $\mathrm{C} / \mathrm{N}$ ratio (Silva et al., 2007), that does not favor the initial development of the subsequent crop. In contrast, legumes such as hairy vetch (Vicia villosa) and clover (Trifolium vesiculosum) are alternatives to increase $\mathrm{N}$ availability in the soil for succession crops because they can biologically fix atmospheric $\mathrm{N}_{2}$ by symbiosis with specific bacteria (Hooker et al., 2008). The radish (Raphanus sativus) is another species with great potential to increase nutrient availability in the soil because it is able to extract them from deeper layers (Silva et al., 2007).

The benefits provided by cover crop plants have been reported in several studies and in several crops, such as corn (Silva et al., 2007), broccoli (Burket et al., 1997), melon (Bhardwaj, 2006) and tomato (Abdulbaki et al., 1996; Campiglia et al., 2010) but there is little information about the winter cover crop preceding tomato cropping. Thus the objective of the present study was to assess different soil cover crops on the agronomic performance of processing tomato and their effects on soil chemical properties.

\section{MATERIAL AND METHODS}

The experiment was carried out in the State University of the Center West (Unicentro), in Guarapuava, Paraná state, Brazil (2523'01 'S, 51²9'46”W, $1100 \mathrm{~m}$ altitude). According to Köppen, the climate of the region is the $\mathrm{Cfb}$ type (temperate, without a defined dry season, with cool summers and mild winters). The rainfall during the execution of the experiment was $1944 \mathrm{~mm}$, minimum and maximum mean temperatures of 14.7 and $23.3^{\circ} \mathrm{C}$ respectively and relative humidity of the air $79.8 \%$.

The soil in the experimental area is classified as typical clay textured acric red-yellow distrophic latossol (Embrapa, 2006) and presents the following characteristics at the depth of 0-20 cm: $\mathrm{pH}\left(\mathrm{CaCl}_{2}\right)=5.6 ; 3.0 \mathrm{mg}$ $\mathrm{dm}^{-3} \mathrm{P}$ (Mehlich 1); $0.57 \mathrm{cmol}_{\mathrm{c}} \mathrm{dm}^{-3} \mathrm{~K}$; $4.2 \mathrm{cmol}_{\mathrm{c}} \mathrm{dm}^{-3} \mathrm{Ca}$; $4.0 \mathrm{cmol}_{\mathrm{c}} \mathrm{dm}^{-3} \mathrm{Mg}$; $2.48 \mathrm{cmol}_{\mathrm{c}} \mathrm{dm}^{-3} \mathrm{H}+\mathrm{Al}$; and $4.16 \mathrm{~g} \mathrm{dm}^{-3}$ organic matter.

A randomized block design was used with four replications in a split plot design. The main treatments (plots) consisted of winter cover crop plants (oats, hairy vetch, radish and clover) and a fallow area (spontaneous vegetation). The splitplots consisted of four processing tomato hybrids (AP529, AP533, Katia, and Sicílio). The plots measured $4 \times 8 \mathrm{~m}\left(32 \mathrm{~m}^{2}\right)$ and the splitplots measured $4 \times 2 \mathrm{~m}\left(8 \mathrm{~m}^{2}\right)$.

The soil was prepared a month before sowing the cover crop by plowing twice. Later lime was applied at 1.10 $\mathrm{t} \mathrm{ha}^{-1}$ (PRNT 92\%), in function of the soil chemical analysis (SCA). A light grading incorporated the fertilizers. The basic fertilization of the cover crop plants was made one week before sowing according to the SCA and CFSRS recommendations (1995), using $200 \mathrm{~kg} \mathrm{ha}^{-1}$ of the NPK 4-20-20 formula, $712.5 \mathrm{~kg} \mathrm{ha}^{-1}$ simple superphosphate and $487.5 \mathrm{~kg} \mathrm{ha}^{-1}$ potassium chloride $(\mathrm{KCl})$. The species were sown by throwing, with sowing density equivalent to 60 , 20,20 and $10 \mathrm{~kg}$ seeds $\mathrm{ha}^{-1}$ for the cover crops oats, hairy vetch, radish and clover, respectively. All the cover crops were desiccated with $400 \mathrm{~g} \mathrm{ha}^{-1}$ of the Paraquat active ingredient, 130 days after sowing (pre-flowering stage) and lodged by passing a wooden roller pulled by a tractor.

The seeds of the hybrids were sown on 128-well expanded polystyrene trays filled with commercial substrate and kept in a greenhouse for 35 days until they presented four or five definitive leaves. Basic tomato fertilization was applied before transplant, in the transplant row, using $500 \mathrm{~kg} \mathrm{ha}^{-1} \mathrm{NPK}$ 4-30-10 formula, $730 \mathrm{~kg} \mathrm{ha}^{-1}$ triple superphosphate and $67 \mathrm{~kg} \mathrm{ha}^{-1}$ urea. The rows were mulched twice, the first at 30 days and the second at 50 days after transplant, with $183 \mathrm{~kg} \mathrm{ha}^{-1}$ triple superphosphate, $50 \mathrm{~kg} \mathrm{ha}^{-1} \mathrm{KCl}$ and $78 \mathrm{~kg} \mathrm{ha}^{-1}$ urea at each mulching. The seedlings were transplanted to the field at $30 \mathrm{~cm}$ between plant spacing and 150 between row spacing, totaling 72 plants per plot and 18 plants per splitplot.

Pests and diseases were controlled with weekly spraying, alternating the following i.a.: Acephate $(570 \mathrm{~g}$ i.a. ha-1), Triflumurom (150 g i.a. ha $^{-1}$ ) Thiamethoxam (10 g i.a. ha $\left.{ }^{-1}\right)$; copper oxichloride (500 g i.a. ha ${ }^{-1}$ ), Metalaxyl-M (3 g i.a. ha-1), Mancozebe (45 g i.a. ha ${ }^{-1}$ ) and Chlorotalonil (520 g i.a. ha ${ }^{-1}$ ), respectively. Weeds were pulled and removed from all the plots. Spray irrigation was carried out in the dry periods.

The fruits were collected at 90, 97, 104 and 111 days after transplant. For total yield (TP) all the fruits were counted and weighed $\left(\mathrm{t} \mathrm{ha}^{-1}\right)$. The fruits were classified in marketable production (CP) (normal and with slight defects, spotted and deformed) and nonmarketable (serious defects) according to the norms reported by the Ministry of Agriculture and Agrarian Reform Decree 553/1995 (BRASIL, 1995). The CP was determined by the percentage of marketable fruits in relation to the TP. The mean fruit mass $\left(\mathrm{g}_{\text {fruit }}{ }^{-1}\right)$ was determined from the marketable production.

Soil samples were collected to compare the possible variations in the chemical attributes of the soil in function of the cover crop. The sampling was made in the $0-20 \mathrm{~cm}$ layer, with a sampling point in each splitplot. Four sub-samples formed a compound sample referent to the main plot that represented one cover crop. The SCA was made in the week the soil cover crop planted and in the tomato implantation phase.

The variables were submitted to analysis of variance $(\mathrm{F} \leq 0.05)$ and the means compared by the Tukey test $(\mathrm{p} \leq 0.05)$. 


\section{RESULTS AND DISCUSSION}

The highest total yields (TP) were obtained in the treatment where the soil cover crops were hairy vetch and radish, with values of 90.11 and 80.00 $\mathrm{t} \mathrm{ha}^{-1}$, respectively (Table 1 ). However, the radish cover crop did not differ from the cover crop with clover, oats and fallow, that presented TP of 73.47, 69.98 and $71.15 \mathrm{t} \mathrm{ha}^{-1}$, respectively. The beneficial effects of the hairy vetch are related to the greater capacity for nitrogen biological fixing (NBF) that increases the availability of this nutrient for the subsequent crop (Sainju et al., 2005). When correctly managed, it provides quantities of $\mathrm{N}$ equivalent to nitrogen fertilizer in areas without cover crop plants (Carrera et al., 2004). In addition, the hairy vetch low $\mathrm{C} / \mathrm{N}$ ratio resulted in greater and faster cycling of nutrients brought up by the cover crop through mineralization (Brandsaeter $e t$ al., 2008). Increments in the tomato TP were shown in some studies that used the hairy vetch cover crop. Campiglia et al. (2010) observed approximate TP of $100,86,78$ and $66 \mathrm{tha}^{-1}$ for the cover crops hairy vetch, clover, fallow and oats, respectively. Abdulbaki et al. (1996) observed 32\% increase in TP in tomatoes cropped after hairy vetch cover crop, increasing not only the TP but also the mean fruit mass.

The increase in the TP provided by the radish may have been related to high nutrient release, especially the macronutrients, in the initial decomposition period (Crusciol et al., 2005). Thus the initial development of the tomato was probably favored after this cover crop. Similar results were obtained with onion (Wang et al., 2008) and corn (Silva et al., 2007), that increased TP when planted after the radish crop.

Although clover has similar characteristics to hairy vetch, such as high FBN capacity and low $\mathrm{C} / \mathrm{N}$ ratio, beneficial effects were not observed for the tomato for TP. This fact may be related to the slow initial establishment of the cover crop and low biomass production that therefore reduce nutrient cycling. Similar results were reported by Assmann et al. (2007), who observed

Table 1. Influence of five cover crops over total and marketable production, average mass and number of marketable fruits from four processing tomato hybrids (influência de cinco coberturas de solo sobre a produtividade total, comercial, massa média e número de frutos comerciais de quatro híbridos de tomate industrial). Guarapuava, UNICENTRO, 2010.

\begin{tabular}{|c|c|c|c|c|c|}
\hline \multirow{2}{*}{ Cover crop } & AP529 & AP533 & Kátia & Sicílio & \multirow{2}{*}{ Means } \\
\hline & \multicolumn{4}{|c|}{ Total yield (t/ha) } & \\
\hline Hairy vetch & 103.82 a A & 95.76 a $\mathrm{A}$ & 85.48 a $\mathrm{AB}$ & 75.37 a $B$ & $90.11 \mathrm{a}$ \\
\hline Radish & $81.35 \mathrm{~b} \mathrm{AB}$ & 98.86 a $\mathrm{A}$ & $74.51 \mathrm{~b} \mathrm{AB}$ & $65.27 \mathrm{~b} \quad \mathrm{~B}$ & $80.00 \mathrm{ab}$ \\
\hline Clover & $82.78 \mathrm{~b} \mathrm{~A}$ & $89.67 \mathrm{ab} A$ & $69.58 \mathrm{~b} \mathrm{AB}$ & $51.86 \mathrm{c} \mathrm{B}$ & $73.47 \mathrm{~b}$ \\
\hline Oats & $87.30 \mathrm{bA}$ & $85.22 \mathrm{~b} \quad \mathrm{AB}$ & $55.53 \mathrm{c} \mathrm{B}$ & 51.85 c B & $69.98 \mathrm{~b}$ \\
\hline Fallow area & $81.97 \mathrm{~b} \mathrm{~A}$ & 79.62 b B & $65.33 \mathrm{~b} \mathrm{~B}$ & $57.69 \mathrm{bc} \mathrm{B}$ & $71.15 \mathrm{~b}$ \\
\hline \multirow[t]{2}{*}{ Means } & $87.44 \quad \mathrm{~A}$ & $89.83 \quad \mathrm{~A}$ & $70.10 \quad \mathrm{~B}$ & $60.41 \quad \mathrm{C}$ & \\
\hline & \multicolumn{4}{|c|}{ Marketable yield (\%) } & Means \\
\hline Hairy vetch & 83.46 a A & $78.77 \mathrm{ab} A B$ & 77.98 a $\mathrm{AB}$ & 70.22 a $B$ & $77.36 \mathrm{a}$ \\
\hline Radish & 85.67 a A & $88.00 \mathrm{a} \mathrm{A}$ & 79.61 a $A B$ & 72.16 a B & $81.36 \mathrm{a}$ \\
\hline Clover & 84.64 a A & $83.28 \mathrm{ab} \mathrm{A}$ & 82.62 a $\mathrm{A}$ & 76.84 a A & $85 \mathrm{a}$ \\
\hline Oats & 88.09 a A & $82.09 \mathrm{ab} \mathrm{AB}$ & 80.44 a $\mathrm{AB}$ & 72.52 a $B$ & $80.79 \mathrm{a}$ \\
\hline Fallow a & 81.67 a A & $72.29 \mathrm{~b} \quad \mathrm{~A}$ & 79.18 a A & $75.54 \mathrm{a} \mathrm{A}$ & $77.17 \mathrm{a}$ \\
\hline \multirow[t]{2}{*}{ Means } & $84.70 \quad \mathrm{~A}$ & $80.89 \quad \mathrm{~A}$ & $79.76 \quad \mathrm{~A}$ & 73.46 & \\
\hline & \multicolumn{4}{|c|}{ Mean mass of marketable fruits (g/fruit) } & Means \\
\hline Hairy vetch & 75.11 a B & 75.17 a B & 76.64 a B & $107.34 \mathrm{a} A$ & $83.56 \mathrm{a}$ \\
\hline Radish & 72.73 a B & 77.12 a $B$ & 65.57 a $B$ & $101.80 \mathrm{ab} \mathrm{A}$ & $79.30 \mathrm{ab}$ \\
\hline Clover & 74.98 a $\mathrm{AB}$ & $80.21 \mathrm{a} A B$ & 73.77 a $\mathrm{B}$ & $90.53 \mathrm{ab} A$ & $79.87 \mathrm{ab}$ \\
\hline Oats & 82.56 a A & 74.70 a $\mathrm{A}$ & 72.52 a $\mathrm{A}$ & $85.19 \mathrm{~b} \mathrm{~A}$ & $78.74 \mathrm{~b}$ \\
\hline Fallow area & 65.47 a B & 70.77 a B & 72.43 a B & $88.97 \mathrm{~b} \quad \mathrm{~A}$ & $74.41 \mathrm{c}$ \\
\hline \multirow[t]{2}{*}{ Means } & $74.17 \quad \mathrm{~B}$ & $75.59 \quad \mathrm{~B}$ & 72.19 & 94.76 & \\
\hline & \multicolumn{4}{|c|}{ Marketable fruits/ha } & Means \\
\hline Hairy vetch & 469 a $\mathrm{A}$ & 419 b A & 373 a $\mathrm{A}$ & 182 a $\mathrm{B}$ & $361 \mathrm{~b}$ \\
\hline Radish & 495 a A & 589 a $\mathrm{A}$ & 466 a A & 257 a $B$ & 452 a \\
\hline Clover & 480 a $A$ & $476 \mathrm{ab} \mathrm{A}$ & 401 a $\mathrm{A}$ & 230 a $B$ & $397 \mathrm{ab}$ \\
\hline Oats & 496 a $\mathrm{A}$ & $495 \mathrm{ab} A$ & 316 a $\mathrm{B}$ & 232 a B & $386 \mathrm{ab}$ \\
\hline Fallow area & 520 a A & $470 \mathrm{ab} A$ & 386 a $\mathrm{AB}$ & $261 \mathrm{a} \mathrm{B}$ & $410 \mathrm{ab}$ \\
\hline Means & $492 \mathrm{~A}$ & $490 \quad \mathrm{~A}$ & $388 \quad \mathrm{~B}$ & $232 \quad \mathrm{C}$ & \\
\hline
\end{tabular}

${ }^{1}$ Means followed by the same uppercase letter in the line and lowercase letter in the column, do not differ among themselves by the Tukey test $(\mathrm{p} \leq 0,05)$ [médias seguidas pela mesma letra maiúscula na linha e minúscula na coluna não diferem entre si pelo teste de Tukey $(\mathrm{p} \leq 0,05)]$.

the slow establishment of clover in the first year because the symbiotic bacteria were beginning colonization and establishing themselves in the soil.

Oats were less effective as a cover crop preceding the tomato crop because of the characteristics intrinsic to its biomass, especially regarding the $\mathrm{C} / \mathrm{N}$ ratio. Contrary to the legumes, oat biomass has a slow mineralization process because the quantity of $\mathrm{N}$ available in the straw is not enough for the decomposing microbiota, that implies immobilization and decrease in the availability of certain nutrients for the subsequent crops (Aita et al., 2001). According to Aita \& Giacomini (2003) only $40 \%$ of the $\mathrm{N}$ contained in oat residues are available in the first four weeks after the management.

The hybrid TP ranged from 51.85 $\mathrm{t} \mathrm{ha}^{-1}$ to $103.82 \mathrm{t} \mathrm{ha}^{-1}$, and the hybrids AP529 and AP533 were outstanding, with $87.44 \mathrm{t} \mathrm{ha}^{-1}$ and $89.83 \mathrm{t} \mathrm{ha}^{-1} \mathrm{TP}$, respectively (Table 1). The TP presented by the AP529 and AP533 hybrids corroborated with the values observed by Seleguini (2005), who reported productivity above $97.0 \mathrm{t} \mathrm{ha}^{-1}$ for these hybrids. Generally the tomato TP ranges 
Table 2. Soil chemical attributes before and after cultivation of five cover crops (atributos químicos do solo antes e após o cultivo de cinco coberturas de solo). Guarapuava, UNICENTRO, 2010.

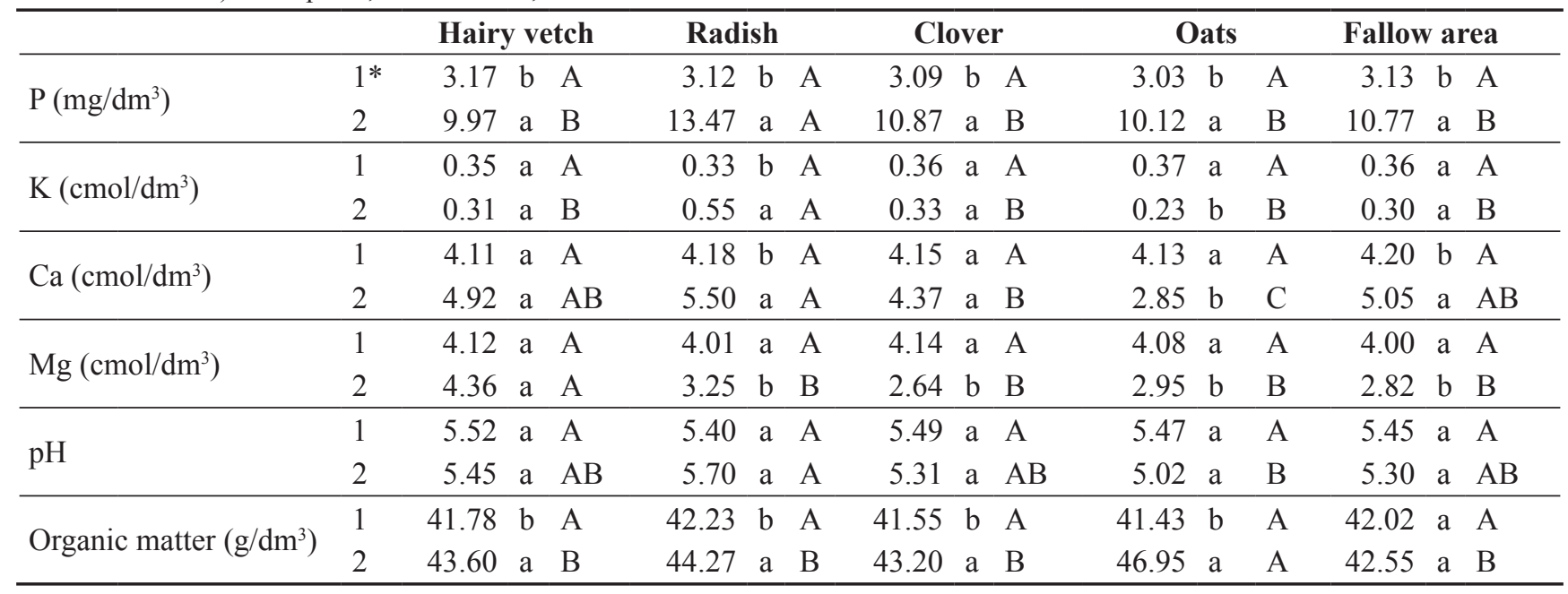

Means followed by the same uppercase letter in the line and lowercase in the column, inside the same analyzed factor, do not differ statistically among themselves by the Tukey $(\mathrm{p} \leq 0,05)$ test.* 1 and $2=$ first and second stage of AQS (médias seguidas pela mesma letra maiúscula na linha e minúscula na coluna, dentro do mesmo fator analisado, não diferem estatisticamente entre si pelo teste de Tukey ( $\mathrm{p} \leq 0,05)$. ${ }^{*} \mathrm{e}$ 2=primeira e segunda época da AQS).

from 52.0 t ha $^{-1}$ to 124.3 tha $^{-1}$ (Resende \& Costa, 2000; Aragão et al., 2004; Seleguini, 2005), and is therefore in agreement with the results of the present study. Nevertheless, when the TP was compared of the four hybrids with the national mean of the industrial tomato, that is from 75 and $80 \mathrm{t} \mathrm{ha}^{-1}$, only the Sicílio TP was less.

Although hairy vetch increased the $\mathrm{TP}$, there was no difference among the cover crops for marketable productivity (CP) except for the AP533 hybrid, in which the radish provided greater $\mathrm{CP}$ than fallow (Table 1). The Sicílio hybrid that presented greater TP with hairy vetch, did not differ for $\mathrm{CP}$, indicating that the increase in the TP provided by the hairy vetch was of low quality fruits. The same was observed for the Katia hybrid that presented a greater TP when preceded by hairy vetch than by oats, but differences were not observed regarding the CP between the two cover crops. Neither was any difference observed among the cover crops for CP. Increase in the CP was expected with the use of leguminous plants, such as observed by Campiglia et al. (2010), where the hairy vetch cover crop increased the tomato fruit $\mathrm{CP}$ compared to the oats and fallow cover crops.

The cover crop plants did not influence the mean marketable fruit mass (MCFM) of the AP529, AP533 and Katia hybrids. In the Sicílio hybrid, hairy vetch increased the MCFM (107.3 g) but did not differ from the radish $(101.8 \mathrm{~g})$ and clover $(90.5 \mathrm{~g})$ cover crops. Although it is a less productive hybrid, Sicílio presented the greatest MCFM (94.76 g). This fact was related to the fruit shape, that is similar to the fruit of the Santa Cruz group, that can present fruits of up to $200 \mathrm{~g}$ (Alvarenga, 2004). Although the AP533 (75.59 g) and AP529 (74.17 g) hybrids presented lower MCFM compared to the Sicílio hybrid, they were within the expected for industrial tomatoes (Resende \& Costa, 2000).

The Sicílio hybrid presented the greatest MCFM, but its TP was below the expected. This fact was related to the lower number of marketable fruits (NCF) that was the half the number observed for the AP529 and AP533 hybrids (Table 1). Fruit size is linked mainly to position in the inflorescence and the genotype, but it also depends on the total of the assimilates produced by the photosynthesis area and the number of fruits that compete for these assimilates (Cockshull \& Ho, 1995).

The phosphorous (P) content in the soil increased in all the treatments due to the base fertilizer of the cover crop. Even so, using the radish cover crop increased the P content in the soil, making $13.47 \mathrm{mg} \mathrm{dm}^{-3} \mathrm{P}$ available in the tomato implantation phase. The calcium $(\mathrm{Ca})$ and potassium $(\mathrm{K})$ contents also increased with the radish cover crop, similar to that observed for P (Table $2)$. The increase in $P$ concentration provided by the radish was related to the high capacity of the crop uptake these nutrients at depth. Thus, because the crop has a high concentration of these nutrients in the canopy and its crop residues degrade quickly after management, the nutrients return contained in the biomass of the plant and soil (Crusciol et al., 2005). The increase in nutrient availability may be one of the factors responsible for the increase in TP of the soil cropped with radish, providing beneficial effects for the subsequent crop.

If on the one hand the radish uptaken and released the nutrients after the end of the crop cycle, the oats had an inverse effect, decreasing the $\mathrm{Ca}$ and $\mathrm{K}$ availability. Two factors conferred this characteristic to the crop: high demand for these nutrients and slow decomposition rate of the crop remains due to the greater $\mathrm{C} / \mathrm{N}$ ratio (35/1) (Aita et al., 2001; Giacomini et al., 2003).

The $\mathrm{pH}$ did not vary between the first and second SCA but compared to the cover crops in the second SCA, the soil 
cropped with radish presented greater $\mathrm{pH}$ than the oats cover crop. These results may be because the residual material from oat straw is more difficult to decompose and tends to acidify the soil more because carbon dioxide is produced in the biological oxidation process of organic compounds, that react with water forming carbonic acid that disassociates releasing protons $(\mathrm{H}+)$ and can acidify the soil (Sousa et al., 2007). On the other hand, the high $\mathrm{pH}$ of the soil in the radish cover crop in the second SCA was attributed to the chemical constitution of the species, that favors fast deposition of the biomass and alkalinization of the soil. Similar results were observed by Amaral et al. (2004), who reported that radish residues were more efficient in soil alkalinization than hairy vetch and oats residues. These authors attributed this fact to the $\mathrm{pH}$ neutralizing capacity and to increase in $\mathrm{Ca}^{2+}$ and $\mathrm{Mg}^{2+}$ in the soil due to the characteristics inherent to the residues of the species.

All the cover crops increased the organic matter (OM) of the soil between the first and second SCA, with an increase of approximately $2 \mathrm{~g} \mathrm{dm}^{-3}$. Oats presented the greatest increase in the soil OM $(13 \%)$ and this fact was related to the high production of plant mass provided by the oats (Giacomini et al., 2003) and the low decomposition rate (Aita et al., 2001). These results corroborated those observed by Gonçalves \& Ceretta (1999), who assessed four cover crop plants and observed increase in soil OM in the oat cropped. Decomposition of the plant material added to the soil is subject to the interference of innumerable factors, such as climate (temperature and humidity), plant material composition (lignin, polyphenols $\mathrm{C} / \mathrm{N} / \mathrm{P} / \mathrm{S}$ ratio), in addition to the characteristics inherent the soil (texture, mineralogy, fertility, topography, microbiota) and the management system adopted (Silva \& Mendonça, 2007). Therefore the lower OM values observed in the radish, hairy vetch and clover treatments must have been associated to the fast mineralization according to the specific characteristics of each species.

The hairy vetch and radish cover crops increased industrial tomato productivity but did not increase the marketable production. The oats cover crop increased soil OM, that was not reflected in the productive increase of the tomato in the first cropping cycle. The radish cover crop preceding tomato cropping increased the availability of $\mathrm{P}$, $\mathrm{Ca}$ and $\mathrm{K}$ to the crop.

\section{REFERENCES}

ABDULBAKI AA; STOMMEL JR; WATADA AE; TEASDALE JR; MORSE RD. 1996. Hairy vetch mulch favorably impacts yield of processing tomatoes. Hortscience 31: 338-340.

AITA C; BASSO CJ; CERETTA CA; GONÇALVES CN; DA ROS CO. 2001. Plantas de cobertura de solo como fontes de nitrogênio ao milho. Revista Brasileira de Ciência do Solo 25: 157-165.

AITA C; GIACOMINI SJ. 2003. Decomposição e liberação de nitrogênio de resíduos culturais de plantas de cobertura de solo solteiras e consorciadas. Revista Brasileira de Ciência do Solo 27: 601-612.

ALVARENGA MAR. 2004. Tomate: produção em campo, casa-de-vegetação e hidroponia. Lavras: UFLA. 400p.

AMARAL AS; ANGHINONI I; HINRICHS R; BERTOL I. 2004. Movimentação de partículas de calcário no perfil de um cambissolo em plantio direto. Revista Brasileira de Ciência do Solo 28: 359-367.

ARAGÃO FAS; GIORDANO LDB; MELO PCT; BOITEUX LS. 2004. Desempenho de híbridos experimentais de tomateiro para processamento industrial nas condições edafoclimáticas do cerrado brasileiro. Horticultura Brasileira 22: 529-533.

ASSMANN TS; ASSMANN AL; SOARES AB; CASSOL LC; GIASSON MS; GIASSON NF. 2007. Fixação biológica de nitrogênio por plantas de trevo (Trifolium spp) em sistema de integração lavoura-pecuária no Sul do Brasil. Revista Brasileira de Zootecnia 36: 1435-1442.

BAETS S; POESEN J; MEERSMANS J; SERLET L. 2011. Cover crops and their erosion-reducing effects during concentrated flow erosion. Catena 85: 237-244.

BHARDWAJ HL. 2006. Muskmelon and sweet corn production with legume cover crops. Hortscience 41: 1222-1225.

BORKERT CM; GAUDÊNCIO CDA; PEREIRA JE; PEREIRA LR; OLIVEIRA JUNIOR AD. 2003. Nutrientes minerais na biomassa da parte aérea em culturas de cobertura de solo. Pesquisa Agropecuaria Brasileira 38: 143-153.

BRANDSAETER LO; HEGGEN H; RILEY H; STUBHAUG E; HENRIKSEN TM. 2008. Winter survival, biomass accumulation and $\mathrm{N}$ mineralization of winter annual and biennial legumes sown at various times of year in Northern Temperate Regions. European Journal of Agronomy 28: 437-448.

BRASIL. 1995. Ministério da Agricultura do
Abastecimento e da Reforma Agrária. Portaria $\mathrm{n}^{\circ} 553$ de 30 de agosto de 1995. Diário Oficial da República Federativa do Brasil, Brasília.

BURKET JZ; HEMPHILL DD; DICK RP. 1997. Winter cover crops and nitrogen management in sweet corn and broccoli rotations. Hortscience 32: 664-668.

CAMPIGLIA E; MANCINELLI R; RADICETTI E; CAPORALI F. 2010. Effect of cover crops and mulches on weed control and nitrogen fertilization in tomato (Lycopersicon esculentum Mill.). Crop Protection 29: 354363.

CARRERALM;ABDUL-BAKIAA; TEASDALE JR. 2004. Cover crop management and weed suppression in no-tillage sweet corn production. Hortscience 39: 1262-1266.

CFSRS/SC - COMISSÃO DE FERITLIDADE DO SOLO. 1995. Recomendações de adubação e calagem para o Estado do Rio Grande do Sul e Santa Catarina: $3^{\mathrm{a}}$ ed. Passo Fundo, RS. 223p.

COCKSHULL KE; HO LC. 1995. Regulation of fruit size by plant density and truss thinning. Journal of Horticultural Science 70: 395-407.

CRUSCIOL CAC; COTTICA RL; LIMA EDV; ANDREOTTI M; MORO E; MARCON E. 2005. Persistência de palhada e liberação de nutrientes do nabo forrageiro no plantio direto. Pesquisa Agropecuaria Brasileira 40: 161-168.

EMBRAPA. Centro Nacional de Pesquisa de Solos. 2006. Sistema brasileiro de classificação de solos. Rio de Janeiro: Embrapa. 306p.

GIACOMINI SJ; AITA C; VENDRUSCOLO ERO. 2003. Matéria seca, relação $\mathrm{C} / \mathrm{N}$ e acúmulo de nitrogênio, fósforo e potássio em misturas de plantas de cobertura de solo. Revista Brasileira de Ciência do Solo 27: 325-334.

GONÇALVES CN; CERETTA CA. 1999. Plantas de cobertura de solo antecedendo o milho e seu efeito sobre o carbono orgânico do solo, sob plantio direto. Revista Brasileira de Ciência do Solo 23: 307-313.

HOOKER KV; COXON CE; HACKETT R; KIRWAN LE; O'KEEFFE E; RICHARDS KG. 2008. Evaluation of cover crop and reduced cultivation for reducing nitrate leaching in Ireland. Journal of Environmental Quality 37: 138-145.

RESENDE GM; COSTAND. 2000. Produtividade de tomate industrial no Vale do São francisco Horticultura Brasileira 18: 126-129.

RUFFO ML; BOLLERO GA. 2003. Modeling rye and hairy vetch residue decomposition as a function of degree-days and decompositiondays. Agronomy Journal 95: 900-907.

SAINJU UM; WHITEHEAD WF; SINGH BP. 2005. Biculture legume-cereal cover crops for enhanced biomass yield and carbon and nitrogen. Agronomy Journal 97: 1403-1412.

SAINJU UM; WHITEHEAD WF; SINGH BP; WANG S. 2006. Tillage, cover crops, and nitrogen fertilization effects on soil nitrogen and cotton and sorghum yields. European Journal of Agronomy 25: 372-382.

SELEGUINI A. 2005. Hibridos de tomate industrial cultivados em ambiente protegido e campo, visando produção de frutos para mesa. Ilha Solteira: UNESP. 71p (Dissertação 
mestrado)

SILVAAAD; SILVA RFD; SUHRE E; ARGENTA G; STRIEDER ML; RAMBO L. 2007.

Sistemas de coberturas de solo no inverno e seus efeitos sobre o rendimento de grão do milho em suscessao. Ciência Rural 37: 928-935.

SILVA IRD; MENDONÇA ESD. 2007. Matéria orgânica do solo. In: Novais RF; Victor HAV; BARROS NF; FONTES RLF; CANTARUTTI NEVES JCL (eds). Fertilidade do solo. Viçosa: Sociedade Brasileira de Ciência do solo. p. 1017.

SOUSA DMG; MIRANDA LN; OLIVEIRA SA. 2007. Acidez do solo e sua correção. In: Novais RF; Victor HAV; BARROS NF; FONTES
RLF; CANTARUTTI NEVES JCL (eds). Fertilidade do solo. Viçosa: UFV. p. 275-274. WANG G; NGOUAJIO M; WARNCKE DD. 2008. Nutrient cycling, weed suppression, and onion yield following brassica and sorghum sudangrass cover crops. HortTechnology 18: 68-74. 